\begin{tabular}{|c|c|c|}
\hline INESEG & $\begin{array}{l}\text { INTERNATIONAL } \\
\text { ENGINEERING, } \\
\text { SCIENCE AND } \\
\text { EDUCATION } \\
\text { GROUP }\end{array}$ & 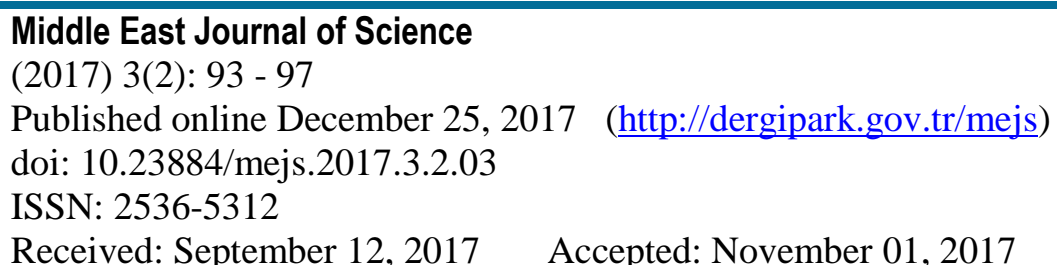 \\
\hline
\end{tabular}

\title{
THE EFFECT OF DIFFERENT HORMONE CONCENTRATIONS AND SQUARE LENGTH ON CALLUS FORMATION IN COTTON ANTHERS
}

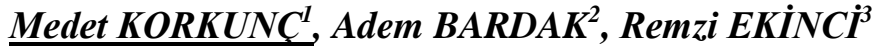 \\ ${ }^{1}$ Dicle University, Diyarbakir Agriculture Vocational School Diyarbakir, Turkey, \\ ${ }^{2}$ Kahramanmaras Sutcu Imam University, Faculty of Agriculture, Department of Agricultural \\ Biotechnology, Kahramanmaras, Turkey. \\ ${ }^{3}$ Dicle University, Faculty of Agricultural, Departman of Fields Crops, Diyarbakir, Turkey, \\ Corresponding author: medet.korkunc@dicle.edu.tr
}

\begin{abstract}
Cotton is a hot climatic industrial plant commonly planted in both tropical and subtropical regions of the world. Four different genotypes of cotton, Aşkabat-100 (G. barbadense L.), Coker-312 and Stoneville-468 (G. hirsutum L.), were studied for callus induction. The cotton anthers extracted from immature floral buds (square) were used as explants. Cotton anthers taken from different length immature cotton square were used as explants. After samples taken from cotton, square of different lengths $(2,3,4,5 \mathrm{~mm})$ were subjected to sterilization with different NaoCl concentrations (10, 20 and 30\%) prepared in sterilized glass containers for surface sterilization, the immature anthers were extracted and placed in MS feeding media with various amounts of different hormones to induce callus formation. After the seeding done, lids of the petri dishes closed, to prevent the air inflow and outflow were covered with parafilms, then the petri dishes were left for dark in the climate room for about 30 60 days. The experiments were performed with three repetitions. Seeding was done every three days and callus size and regeneration rates that resulted from 5-week dark environment incubation were determined. Once the anthers were transferred to the induction media, one-hour cold $\left(4^{\circ} \mathrm{C}\right)$ shock and one-hour hot shock $\left(40^{\circ} \mathrm{C}\right)$ were applied to them, they were kept in dark for a while and were left for collagenase in climate room at 16/24 light regime. As the result of the experiments, the highest rate of callus formation was observed in Cooker 312 supplemented with $2 \mathrm{mg} \mathrm{mL}^{-1}$ of NAA and $2 \mathrm{mg} \mathrm{L}^{-1}$ of BA hormones. Callus formation was also higher in the treatment where NAA was used than the media supplemented with 2,4-D. Additionally, callus formation showed better results in cold and hot shock applied anthers compared to the ones that were not shocked.
\end{abstract}

Key Words: Cotton, Floral buds, square, anther, callus

\section{Introduction}

Cotton, with its various areas of use, is one of the crops that have a significant place in the sectors of agriculture, trade and industry all around the world. Cotton fiber accepted as the ideal textile 
product for its structural properties [2]. Besides its fiber, seeds and residues that contain oil and protein are considered as an important animal food [9].

Among the various tissue culture methods used in cotton studies, anther culture is one of the important culturing method. However, anther culturing studies have not reached the desired level yet [4]. It is quite difficult to generate callus from cotton anthers. In a study carried out by [7], three different genotypes of cotton were used to generate callus from the immature ovules and anthers. In the study, they used MS feeding media, some auxins derivatives such as 2,4-D, IAA, IBA and Kinetin. However, they were not able to induce the callus formation from anthers while they obtained $88 \%$ success for ovules. At the end of the study, they reported that the amount of callus dropped when the concentration of 2,4-D was brought over $3 \mathrm{mg} \mathrm{l}^{-1}$ and $4 \mathrm{mg} \mathrm{l}^{-1}$ [7].

In this study, we aimed at culturing the anthers extracted from immature buds in an appropriate feeding media by using different concentrations of a variety of hormones and at inducing callus formation in them [5].

\section{Material and Methods}

Three genotypes belonging to two cultivated species i.e G. barbadense (Aşkabat-100) and $G$. hirsutum (Coker 312, Stoneville-453 and Stoneville-468) are the biological materials of this study.

A total of 120 pots; each genotype of 40 pots containing 4 seeds were prepared and were grown in Green House. All other required work, such as watering carried for seeds to germinate and for plants to grow, was performed whenever necessary. After germination, a thinning was made so that each pot had only one plant.

After initial square, each square was labeled with a sticker that indicated its squaring time. Later, an average of 100 squares was calculated from each genotype every day until there were no buds on the plants. The extracted floral buds were measured by compass and were categorized as 2, 3, 4 and $5 \mathrm{~mm}$ [3-4].

For the surface sterilization of the collected buds, first $80 \%$ autoclaved with distilled water and $20 \%$ hyposolution was prepared, 3 drops of tween 20 was dropped then shaked for 15 minutes and finally they were rinsed with sterile pure water. In this study, pre-prepared MS feeding media and concentrations of auxins deriatives; NAA, IBA and 2,4-D with kinetin, to different feeding media of BA and TDZ 5. Three replicates of sterilized anthers from each category $((2 \mathrm{~mm}, 3 \mathrm{~mm}, 4 \mathrm{~mm}$ ve $5 \mathrm{~mm})$ of each genotype in a pethri dish were cultured with the help of bisturi and pens [8].

Following the culture, the lids of the petri dishes were closed, and they were stretch-filmed to avoid any contamination. After anthers were transferred to the induction media, one-hour cold shock (+ $\left.4^{\circ} \mathrm{C}\right)$ and one-hour hot shock $\left(40^{\circ} \mathrm{C}\right)$ were applied, they were kept in for a while and were taken to the growth room with $16 / 24$ photoperiod conditions.

\section{Discussions}

The callus production rates of cotton genotypes investigated in 7 different feeding media given in Table 1. Callus production rates (\%), depending on the genotype, varied between 0.0 and 4.8 (Table 1). The callus production rate of Coker-312 genotype in $3 \mathrm{mg} / \mathrm{L} \mathrm{NAA}+2 \mathrm{mg} / \mathrm{L} \mathrm{BA}+0,5 \mathrm{mg} / \mathrm{L} \mathrm{TDZ}$ ve $2 \mathrm{mg} / \mathrm{l}$ 2,4-D + $2 \mathrm{mg} / \mathrm{l} \mathrm{NAA}+2 \mathrm{mg} / \mathrm{l} \mathrm{Kinetin}+2 \mathrm{mg} / \mathrm{l} \mathrm{BA}$ supplemented feeding media varied between 
1.1 and 4.8, whereas the lowest callus production rate was observed in Askabat-100 genotype in $1 \mathrm{mg} / \mathrm{L}$ $\mathrm{NAA}+1 \mathrm{mg} / \mathrm{l} \mathrm{BA}, 2 \mathrm{mg} / \mathrm{L} \mathrm{NAA}+1 \mathrm{mg} / \mathrm{l} \mathrm{BA}$ and $2 \mathrm{mg} / \mathrm{l}$ 2,4-D + $2 \mathrm{mg} / \mathrm{l} \mathrm{NAA}+2 \mathrm{mg} / \mathrm{l} \mathrm{Kinetin+2} \mathrm{mg/l}$ BA supplemented feeding media with range 0.0-1.1. Within the range of this study, Coker-312 genotype used as a material formed the group that had the highest rate of callus production, whereas Askabat-100 formed the group that had the lowest callus production [6].

Table 1. Average number of the callus formation in MS feeding media with various concentrations of tested hormones.

\begin{tabular}{|l|c|c|l|c|}
\hline \multirow{2}{*}{ Media Component } & \multicolumn{5}{|c|}{ Number of Callus Formed by Each Genotype } \\
\cline { 2 - 5 } & Coker 312 & Aşkabat 100 & Stoneville 453 & Stoneville 468 \\
\hline $1 \mathrm{mg} / \mathrm{L} \mathrm{NAA}+1 \mathrm{mg} / \mathrm{l} \mathrm{BA}$ & 3.5 & 2.6 & 0 & 0.1 \\
\hline $2 \mathrm{mg} / \mathrm{L} \mathrm{NAA}+1 \mathrm{mg} / \mathrm{L} \mathrm{BA}$ & 2 & 3 & 0 & 0.1 \\
\hline $\begin{array}{l}2 \mathrm{mg} / \mathrm{l} 2,4-\mathrm{D}+2 \mathrm{mg} / \mathrm{l} \mathrm{NAA} \\
+1 \mathrm{mg} / \mathrm{l} \mathrm{Kinetin} 1 \mathrm{mg} / \mathrm{l} \mathrm{BA}\end{array}$ & 4 & 2.87 & 0.2 & 0.5 \\
\hline $\begin{array}{l}2 \mathrm{mg} / \mathrm{l} 2,4-\mathrm{D}+2 \mathrm{mg} / \mathrm{l} \mathrm{NAA}+ \\
2 \mathrm{mg} / \mathrm{l} \mathrm{Kinetin}+2 \mathrm{mg} / \mathrm{l} \mathrm{BA}\end{array}$ & 4.8 & 2.85 & 1.1 & 1.4 \\
\hline $\begin{array}{l}1 \mathrm{mg} / \mathrm{l} 2,4-\mathrm{D}+2 \mathrm{mg} / \mathrm{L} \mathrm{NAA} \\
+1 \mathrm{mg} / \mathrm{l} \mathrm{Kinetin}\end{array}$ & 2.55 & 0.8 & 0.21 & 0.66 \\
\hline $\begin{array}{l}3 \mathrm{mg} / \mathrm{L} \mathrm{NAA}+2 \mathrm{mg} / \mathrm{L} \\
\mathrm{BA}+0,5 \mathrm{mg} / \mathrm{L} \mathrm{TDZ}\end{array}$ & 1.1 & 0.5 & 1 & 1.4 \\
\hline $\begin{array}{l}1 \mathrm{mg} / \mathrm{l} \mathrm{NAA}+1 \mathrm{mg} / \mathrm{BA}+0,5 \\
\mathrm{mg} / \mathrm{L} \mathrm{TDZ}\end{array}$ & 2.7 & 1 & 0.2 & 0.6 \\
\hline
\end{tabular}

Among the screened genotypes the highest callus average was determined in Coker-312 with 5.77 (5 mm square length) and the lowest callus average was determined in Askabat-100 with 0.0 (2 $\mathrm{mm}$ square length) (Table 2). Coker-312 genotype yielded higher callus formation averages (\%) than Stoneville-453, Stoneville-468 and Ashkabat-100 genotypes. Callus formation rates varied with anther length ( $\mathrm{mm})$ and types [1].

Table 2. MS Media, viability percent and callus formation versus square

\begin{tabular}{|c|c|c|c|}
\hline \multirow{3}{*}{ Genotype } & $\begin{array}{c}\text { Square } \\
\text { Length } \\
\text { (mm) }\end{array}$ & $\begin{array}{c}\text { Anther } \\
\text { Viability } \\
\mathbf{\%}\end{array}$ & $\begin{array}{c}\text { Number of the Callus } \\
\text { Formed }\end{array}$ \\
\hline \multirow{4}{*}{ Coker 312 } & 2 & 100 & 1.77 \\
\cline { 2 - 4 } & 3 & 100 & 1.88 \\
\cline { 2 - 4 } & 4 & 100 & 3.33 \\
\cline { 2 - 4 } & 5 & 100 & 5.77 \\
\hline \multirow{4}{*}{ Stonville-453 } & 2 & 100 & 1.00 \\
\cline { 2 - 4 } & 3 & 100 & 0.72 \\
\cline { 2 - 4 } & 4 & 100 & 0.43 \\
\hline \multirow{5}{*}{ Askabat-100 } & 5 & 100 & 1.10 \\
\cline { 2 - 4 } & 2 & 100 & 0.00 \\
\cline { 2 - 4 } & 3 & 100 & 2.62 \\
\cline { 2 - 4 } & 4 & 100 & 3.00 \\
\hline \multirow{5}{*}{ Stoneville 468 } & 5 & 100 & 3.25 \\
\cline { 2 - 4 } & 3 & 100 & 1.66 \\
\cline { 2 - 4 } & 4 & 100 & 0.88 \\
\cline { 2 - 4 } & 5 & 100 & 0.66 \\
\hline
\end{tabular}




\section{Results}

As the result of this study, it was observed that the highest numbers of callus were formed in the media supplemented with $2 \mathrm{mg} / \mathrm{l}$ 2,4-D $+2 \mathrm{mg} / \mathrm{l} \mathrm{NAA}+2 \mathrm{mg} / \mathrm{l} \mathrm{Kinetin}+2 \mathrm{mg} / \mathrm{l}$ BA for 3mm of each genotype. Among all the genotypes studied, Coker $312(3 \mathrm{~mm})$ formed the highest amount of callus while Stoneville 468 ( $2 \mathrm{~mm}$ ) genotype showed the lowest one. Besides, the callus formation in the media with 2,4-D was found to be higher than the media supplemented with NAA.

According to obtained findings and results, positive results were obtained in $2 \mathrm{mg} / \mathrm{l} 2,4-\mathrm{D}+2$ mg/l NAA + 2mg/l Kinetin+2 mg/l BA ve 2 mg/l 2,4-D + 2 mg/l NAA +1 mg/l Kinetin 1mg/l BA supplemented feeding media. This situation puts forth the need for the investigation of low doses of different plant growth regulators. As the best results have been obtained in terms of callus production rates from the Coker-312 genotype belonging to G. hirsutum L. species puts forth the idea that better results may be obtained from the types in these species. This situation shows that apart from Coker-312, types such as Coker-310, Stoneville-453 and Stonevile-468 may as well can be used as material in future studies.

\section{Acknowledgement}

We would like to thank Kahramanmaraş Sütçü Imam University Scientific Research Projects (Project number: 2014/2-50D) and TUBITAK BIDEB (2211-C Domestic Priority Areas Doctoral Scholarship Program) for their financial support. This study is a part of the Medet Korkunç's postgraduate thesis. Adem Bardak is a supervisor.

\section{References}

[1] Beasley, C.A. and Ting, I.P., 1973. The effects of plant growth substances on in vitro fiber development from fertilized cotton ovules. Am. J. Bot., 60: 130-139.

[2] Brubaker C. L., ve ark., 1999. The origin and domestication of cotton. (C.W. SMITH, J.T. COTHREN editors) Cotton: Origin, History, Technology, and Production. John Wiley and Sons, Inc., New York, Page: 3-31.

[3] Davidonis, G.H. and R.H. Hamilton, 1983. Plant regeneration from callus tissue of Gossypium hirsutum L. Plant Sci. Lett., 32: 89-93.

[4] Ellıaltıglu, S., Sarı, N., Abak, K. 2000. Haploid Plant Production. (Plant Biotechnology Vol I, Ed: Babaoğlu M. Ozcan, S., Gurel, E.) 40 p.

[5] Jayashanker, R.W., Dani, R.G., Aripkjanov S.A., and A.K.E. Ergashev, 1991. Studies on Thidiazuron mediated in vitro callus induction in Asiatic cottons Adv. Pl. Sci., 4(1):138-142.

[6] Khanna, H.K. and S.K. Raina, 1998. Genotype x culture media interaction effects on regeneration response of three indica cultivars. Plant cell, Tissue and Organ Culture, 52: 145-153.

[7] Memon, S., Mari, S.N., Mari A.K., and N.H. Gaddi. 2010. Induction of callus through anther and ovule culture in upland Cotton (Gossypium hirsutum L.). World Applied Sciences, (Special Issue of Biotechnology \& Genetic Engineering), 8: 76-79 
[8] Murashige, T., Skoog, F., 1962. A revised medium for rapid growth and bioassays with tobacco tissue cultures. Physiol. Plantarum 15: 473-497.

[9] Smith WC (1999) Production statistics. In WC Smith, JT Cothren, eds Cotton: Origin, History, Technology and Production. John Wiley and Sons, Inc., pp 435-449. 